\title{
Critical Success Factors in Accepting Technology in the Classroom
}

\author{
https://doi.org/10.3991/ijet.v16i18.23159 \\ Francisco José Miranda Veiga( $\left.{ }^{\bowtie}\right)$, António Manuel Valente de Andrade \\ Universidade Católica Portuguesa, Porto, Portugal \\ xfveiga@gmail.com
}

\begin{abstract}
The adoption of technology on the individual and organizational level may be a necessary condition, but it is not sufficient for the digital transformation, seen as the mobilizing challenge to do something new and different. Without a strategic vision, we take the risk of acquiring resources to do the same as before, essentially changing the format. This inability imprisons the school to inconsequential models, resources and strategies. Interdisciplinary, social and project-based learning that the most advanced technology provides can be adopted. Augmented and virtual reality, the internet of things, robots, artificial intelligence and digital assistants can bring innovation to teaching. But also mobiles, games, simulators and multimedia can inspire collaborative creativity. On the other hand, the pandemic, in terms of the adoption of technology, constitutes a kind of insurrection against the fatalism that it is not possible to restart the system, that is, rethink the school. This study aims at investigating the degree of acceptance, materialized in the use of technology, by teachers of primary and secondary education, in the context of the classroom. As a methodological support to this study, the model "Unified Theory of Acceptance and Use of Technology" (UTAUT)) was used and a questionnaire applied to teachers at our school, obtaining 90 responses. The analysis of the responses reveals that the expected adoption of information technologies currently has a global performance, which becomes the most significant positive influence on the motivation and involvement of teachers. That is, the availability of technology, the speed of access, the applications suited to the curriculum and to the pedagogical approach are, more and more, a harmonious set that is compatible with its mission. The study also clarifies that teachers intend to use ICT as they see in them a different didactic tool that allows different approaches, thus increasing, in general, the quality of teaching and learning.
\end{abstract}

Keywords-Teaching, Technology, Technology Acceptance and Use

(UTAUT), Teacher Behaviour

\section{Introduction}

We live in a society immersed in technology and information. Computers, tablets, smartphones, smartwatches, among many other gadgets, keep us connected, through the internet, to the globalization of information sources. The dynamics of this reality 
force continuous adaptations. Artificial Intelligence, Internet of Things, augmented and virtual reality, gamification, robots, virtual assistants, 3D printers, digital microscopes, digital laboratories slowly entering our schools are proof of these changes. But will they bring changes to the teaching and learning process? Over the past few years we have seen an increase in the use of technology in the classroom. In fact, the use of computers or other artefacts in education is not a new issue. However, technology is a challenge for teachers either because of its accelerated evolution, or due to the difficulty of adopting new pedagogical methods $[1,2]$. Technology can facilitate the understanding of complex knowledge, by reducing certain degrees of abstraction, through simulators. It can allow a greater involvement, motivation and interdisciplinarity.

Information Technologies (IT) have revolutionised the concepts of time and space and are causing profound changes in the way people can collaborate, integrate communities, explore resources, exchange ideas and learn [3]. Taking into account the fast pace of development, teachers also need continuous learning in order to adapt to new technological resources and improve their technological skills. The introduction of any type of new technology in the classroom is not just a financial or technical issue, it is above all an educational issue [4] .

It is at school that students can learn how to use technology to help transform information into knowledge. If it is true that many schools are equipped with different technological devices, it is also true that many refer that the material is obsolete or the access to the Internet is deficient and is not widespread. However, in all of them, students enter the classroom with their own technology, using mobile devices, often technically more advanced than those of their teachers. This mobile device can become a powerful teaching resource.

Over the past few years, the Almeida Garrett Secondary School (ESAG) has been promoting training sessions related to the use of technology in the classroom, such as the Moodle and Office 365 platforms, active methodologies with Information and Communication Technologies (ICT), which have a portfolio of digital educational resources, teaching and learning platforms and content repositories. Today, more than ever, teachers cannot avoid the use of information technologies in teaching. It is then necessary to know to what extent they have adapted to the new methodologies, the reasons for resisting the changes (when it happens), and what are the issues that hinder their adoption in the classroom. Thus, we propose to investigate methodologically the degree of acceptance of active methodologies with ICT in the classroom, guided by the following objectives: (i) if teachers have the appropriate skills for using ICT in the classroom, (ii) what are the factors of resistance to the pedagogical adoption of ICT in school and (iii) what are the determining factors for their adoption and use in the classroom.

\section{$2 \quad$ UTAUT Model}

What leads people into accepting or rejecting ICT? Its acceptance is a theme that has been investigated over the years in several areas, namely Computer Sciences, Information Systems and Information Science and Organisational Behaviour. These studies 
are carried out through various tests and methods, to assess people's use and behaviour regarding the acceptance and use of IT at a personal and organisational level [5].

A user's acceptance of adopting a new technology can be measured through a variety of models: Fishbein \& Ajze's Theory of Rational Action (TRA) [6]; Davis's Technological Acceptance Model (TAM) [7]; Ajzen's Theory of Planned Behaviour (TPB) ([8]), the Unified Theory of Acceptance and Use of Technology (UTAUT) of Venkatesh et al. [9], among others [10].

One of the widely used reference models is the Technological Acceptance Model [11]. Davis [11] proposed the TAM (Technology Acceptance Model), thus promoting a new approach to the Rational Action Theory (TRA), focused on the intentional conscious behaviour of the use of new technologies. This theory highlights the analysis of external factors such as attitudes and intentions [7]. Thus, the Technological Acceptance Model identifies two constructs that affect the acceptance of computer innovations: (i) Perceived Utility - which refers to the extent that one of the individuals considers that the use of a particular system improves the performance of an activity, and so it brings positive results; (ii) Ease of Use - defined as the extent to which the potential user of a technology predicts that its use does not involve any effort. On the other hand, the Unified Theory of Acceptance and Use of Technology (TUAUT / UTAUT - Unified Theory of Acceptance and Use of Technology) was created with the aim of joining seral studies to analyse the area of IT acceptance [12]. Venkatesh et al [9] highlight that the choice of this model is due to the fact that the models in this theory have already been tested in IT environments and approved by the academic community for being international references. These different models are used in several investigations and, consequently, due to their popularity, a considerable number of questionnaires were built and validated based on the fundamental ideas implied in the UTAUT model [13].

To achieve our goal, the literature review was carried out based on the results obtained through the database "Main Collection of the Web of Science" (WOS). The keywords used for the research in the field - "topic" were "UTAUT" and "education". Bibliometric analysis was performed with the VOSviewer software, which allowed us to create and view bibliometric maps [14] and thus select 20 reference studies that served as the basis for our model, as shown in the figure 1. These studies contemplated the main dimensions of the UTAUT model: (i) Performance Expectancy - PE, (ii) Effort Expectancy - EE, (iii) Social Influence - SI, (iv) Facilitating Conditions - FC, (v) Intention to Use - IU, (vi) Effective Use - EU. 


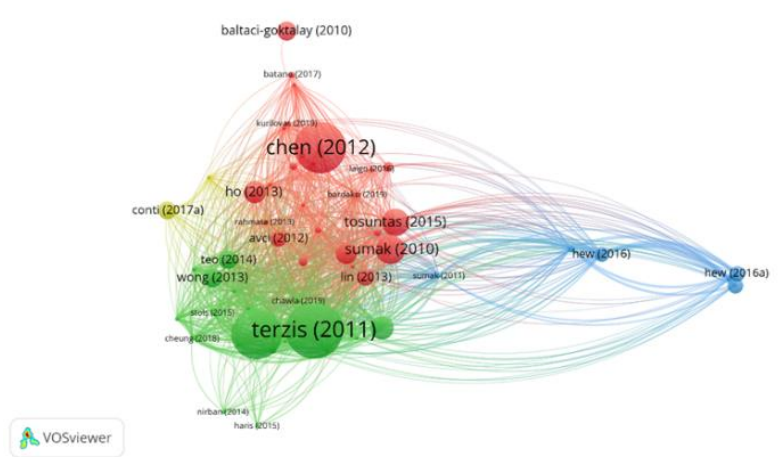

Fig. 1. Network diagram of the most quoted authors

Considering the objectives of this study, an analysis of all articles was made. The articles and the respective constructs are summarised in Table 1.

Table 1. Constructs of the analysed models

\begin{tabular}{|c|c|c|c|c|c|c|c|c|c|c|c|c|}
\hline \multicolumn{8}{|c|}{ UTAUT Model } & \multicolumn{5}{|c|}{ UTAUT Model Moderators } \\
\hline$I D$ & $\begin{array}{c}\text { Refer- } \\
\text { ence }\end{array}$ & $P E$ & $\boldsymbol{E} \boldsymbol{E}$ & $S I$ & FC & $I U$ & $\boldsymbol{E} \boldsymbol{U}$ & Gender & Age & $\begin{array}{c}\text { Experi- } \\
\text { ence }\end{array}$ & $\begin{array}{l}\text { Volun- } \\
\text { tariness }\end{array}$ & $\begin{array}{c}\text { New } \\
\text { modera- } \\
\text { tors }\end{array}$ \\
\hline 1 & [13] & $*$ & $*$ & $\mathrm{x}$ & $\mathrm{X}$ & $\mathrm{X}$ & $\mathrm{x}$ & $\mathrm{X}$ & $\mathrm{X}$ & $\mathrm{x}$ & $\mathrm{X}$ & \\
\hline 2 & [10] & $* *$ & $* *$ & $\mathrm{x}$ & $\mathrm{X}$ & $\mathrm{X}$ & $\mathrm{x}$ & & & & & \\
\hline 3 & [16] & $\mathrm{x}$ & $\mathrm{X}$ & $\mathrm{x}$ & $\mathrm{X}$ & $\mathrm{X}$ & $\mathrm{x}$ & $\mathrm{X}$ & & $\mathrm{x}$ & & $*$ \\
\hline 4 & {$[17]$} & $* *$ & $* *$ & $\mathrm{x}$ & $\mathrm{X}$ & $\mathrm{X}$ & & & & & & \\
\hline 5 & [1] & $\mathrm{x}$ & $\mathrm{X}$ & $\mathrm{x}$ & $\mathrm{X}$ & $\mathrm{X}$ & $\mathrm{x}$ & & & & & $*$ \\
\hline 6 & [2] & $\mathrm{x}$ & $\mathrm{X}$ & $\mathrm{x}$ & $\mathrm{X}$ & $\mathrm{X}$ & & & & & & $*$ \\
\hline 7 & [4] & $\mathrm{x}$ & $\mathrm{X}$ & $\mathrm{x}$ & $\mathrm{X}$ & $\mathrm{X}$ & $\mathrm{x}$ & $\mathrm{X}$ & $\mathrm{X}$ & $\mathrm{X}$ & $\mathrm{X}$ & $*$ \\
\hline 8 & {$[18]$} & $\mathrm{x}$ & $\mathrm{X}$ & $\mathrm{x}$ & $\mathrm{X}$ & $\mathrm{X}$ & $\mathrm{x}$ & & & & & \\
\hline 9 & [19] & $\mathrm{x}$ & $\mathrm{X}$ & $\mathrm{x}$ & $\mathrm{X}$ & $\mathrm{X}$ & $\mathrm{x}$ & $\mathrm{X}$ & $\mathrm{X}$ & & & \\
\hline 10 & {$[20]$} & $\mathrm{x}$ & $* *$ & $*$ & $*$ & $\mathrm{X}$ & & & & & & \\
\hline 11 & {$[21]$} & $\mathrm{x}$ & $\mathrm{X}$ & $\mathrm{x}$ & $\mathrm{X}$ & $\mathrm{X}$ & & & & & & $*$ \\
\hline 12 & [22] & $\mathrm{x}$ & $\mathrm{X}$ & $\mathrm{x}$ & $\mathrm{X}$ & $\mathrm{X}$ & $\mathrm{x}$ & $\mathrm{X}$ & $\mathrm{X}$ & $x$ & $x$ & $*$ \\
\hline 13 & [23] & $\mathrm{x}$ & $\mathrm{X}$ & $\mathrm{x}$ & $\mathrm{X}$ & $\mathrm{X}$ & $\mathrm{x}$ & & & & & $*$ \\
\hline 14 & [24] & $\mathrm{x}$ & $\mathrm{X}$ & ** & $* *$ & $\mathrm{X}$ & & & & & & \\
\hline 15 & [25] & $x$ & $\mathrm{X}$ & $* *$ & $* *$ & $* *$ & & & & & & \\
\hline 16 & [26] & & & & & & & & & & & \\
\hline 17 & [27] & $x$ & $\mathrm{X}$ & $x$ & $\mathrm{X}$ & $\mathrm{X}$ & $\mathrm{x}$ & $\mathrm{X}$ & $\mathrm{X}$ & $x$ & & \\
\hline 18 & {$[28]$} & $\mathrm{x}$ & $\mathrm{X}$ & & & $\mathrm{X}$ & & & & & & $*$ \\
\hline 19 & [29] & $x$ & & & & $\mathrm{X}$ & & & & & & $*$ \\
\hline 20 & [30] & & & $\mathrm{x}$ & $X$ & & & & & & & \\
\hline
\end{tabular}

New constructs were introduced

** The name of the constructs was changed 
The analysis of the identified articles presents different variables to study the acceptance or adoption of technologies, most of which are related to teaching; the results found by the authors are consistent with UTAUT, even for those who proposed changes to the original model. In some articles, UTAUT is combined with other models in order to adapt to the purposes identified by the authors. The analysed models do not use exactly this designation for their constructs, so, the terminology used in table 1 resulted from a categorization process achieved after the analysis of the articles and aims at a synthesis to identify common characteristics. This categorization made it possible to identify the high number of constructs that explain the intention to use a technology, as well as the flexibility of the UTAUT model, the main reason why this model was adopted. The categorization criterion followed was semantics, in which the models were grouped by the similarity of the themes[15]. Several instruments contemplate multiple dimensions, as reflected in Table 1.

\section{Model proposal}

There are different ways of approaching the integration of ICT in a teaching and learning process. In our study, the reference to ICT regards the use of active methodologies with ICT, using a tool or a combination of tools, platforms and digital educational resources such as, for example, Edmodo, Forms, Padlet, Kahoot, Socrative, Photofunia, Animoto and Mentimeter.

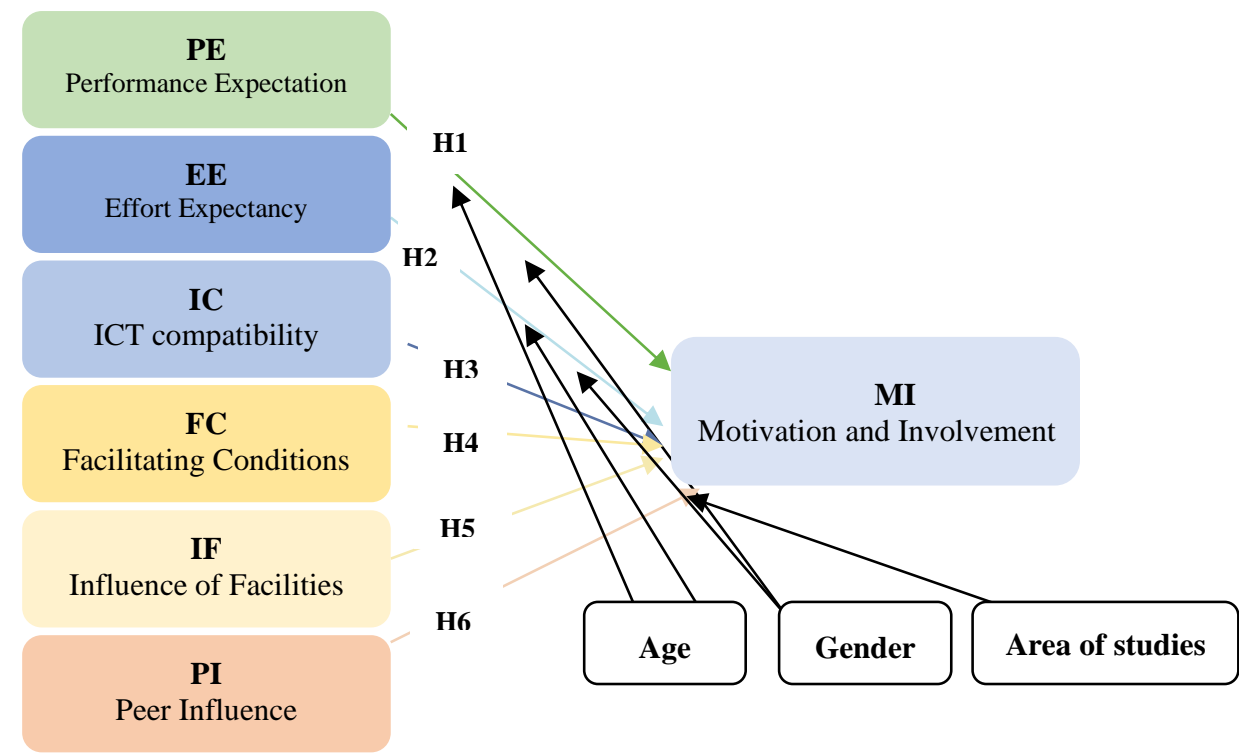

Fig. 2. Research model adapted from UTAUT (Venkatesh et al., 2003) 
The constructs of the UTAUT model have a significant role as direct predictors of the intention to behave, structuring a research model that considers performance expectancy; effort expectancy; social influence; facilitating conditions, and attitudes regarding the adoption intention, behavioural intention, which, in turn, affect the real utilization of a certain system [9]. The atypical pandemic situation we are facing implies that, when applying the questionnaire, teachers are working online with a degree of great uncertainty in relation to the return of face-to-face education. In this context, the name of some constructs were changed and proposed the model presented in figure 1 , in which the focus was on the motivation and involvement of teachers, the intention and / or use of ICT in the classroom.

The purpose of this model is to relate the endogenous variable "motivation and involvement" of teachers to adopt ICT (as didactic tools in the classroom) and a certain number of explanatory or exogenous variables. The variables that we will present resulted from an analysis of technological competences and resistance factors, and address several themes.

\subsection{Performance Expectancy (PE)}

$\mathrm{PE}$ is defined as the degree to which an individual believes that the use of technology will improve his/her performance in his/her activities [9]. Holzmann, Schwarz, \& Audretsch [2] point out that PE is a significant determinant of teachers' intention to use innovative technology in the classroom. In this study, it is assumed that PE represents the degree to which a person believes that the use of a particular ICT resource will increase his/her pedagogical performance and, thus, the student's learning results [2].

H1 - There is a significant relationship between the PE and the MI of the teachers for the use of ICT in the classroom.

\subsection{Effort Expectancy (EE)}

EE comprises aspects related to the ease of use of technology and is defined as the degree of ease that an individual associates with the use of technology [9]. However, in the analysed literature the empirical results for EE differ. Holzmann, Schwarz, \& Audretsch [2] report that half of the existing studies on teacher intent and the use of elearning technology have not found a significant relationship between EE and the intention to use. In this study, as Kouakou [30] did, the performance expectancy of the original model was subdivided: (i) Effort Expectancy and (ii) Compatibility of ICT, thus seeking to overcome the difficulties of the previous studies mentioned above.

So, it is assumed that EE represents the belief about the ease of use of ICT in the classroom by teachers. This construct reflects how comfortable teachers are with the use of ICT in the classroom, that is, it measures the individual's perception of the level of effort required to use ICT in the classroom. It is concluded that the higher the perceived EE (ease of use of technology, convenience), the more likely it is that a teacher intends to adopt the use of ICT in the Classroom.

$\mathrm{H} 2$ - There is a significant relationship between teachers' EE and MI for the use of ICT in the classroom. 


\subsection{ICT compatibility and self-efficacy (IC)}

IC represents the belief of the teacher who easily finds ICT tools and content that meet his syllabus and pedagogical needs. It is assumed that the higher the perceived IC (ease of finding content and tools), the more likely it is that a teacher intends to adopt the use of ICT in the Classroom.

H3 - There is a significant relationship between the IC and the MI of the teachers for the use of ICT in the classroom.

\subsection{Facilitating Conditions (FC)}

FC are defined as the degree to which an individual believes that there is an organisational and technical support infrastructure that helps to use the technology [9]. Holzmann, Schwarz, \& Audretsch [2] state that, for older adults, FC are the second most important predictor of intention to use after EE. The use of technology in the classroom requires specific skills and abilities that differ from traditional pedagogy and resources. In this context, it is natural that, so that teachers are more motivated to adopt technology in the classroom, they have access to resources, technology, education and training, that is, time to learn and practice. Thus, this construct was subdivided, in order to improve the investigation, into: Facilitating Conditions (FC) and System Complexity (SC).

In FC it is deduced that teachers have access to the support needed to use technology in the classroom, which, in turn, will positively affect their intention to use it.

$\mathrm{H} 4$ - There is a significant relationship between the FC and the MI of teachers for the use of ICT in the classroom.

\subsection{System Complexity (SC)}

$\mathrm{SC}$ will be related to the degree of perception that a particular digital educational resource or technology is difficult to understand and or use.

H5 - There is a significant negative relationship between the CS and the MI of teachers for the use of ICT in the classroom.

\subsection{Peer Influence (PI)}

Social influence is defined as the degree to which an individual realises that other fellow teachers believe that technology should be used [9]. In this study, social influence is related to the influence exerted on teachers by close people (for example, principals, colleagues, friends) who believe in the use of technology in the classroom and, in this context, it was decided to change the name of the construct to peer influence.

H6 - There is a significant relationship between PI and the MI of teachers for the use of ICT in the classroom. 


\section{$4 \quad$ Methodology}

\subsection{Participants}

The questionnaire was sent to 119 teachers who taught at ESAG in the academic year 2019/2020 from whom we obtained 90 responses.

Respondents are mostly female ( $83.3 \%$ versus $16.7 \%$ ); with regard to age, we observed that $77.8 \%$ are over 50 years old, only $22.2 \%$ are between 36 and 50 years old and no respondent is between 25 and 35 years old.

Table 2. Characterisation of the sample in terms of gender, age and subject area

\begin{tabular}{|c|c|}
\hline Variables & Characteristics \\
\hline Respondent gender & $\begin{array}{l}16.7 \% \text { (15) Male } \\
83.3 \% \text { (75) Female }\end{array}$ \\
\hline Respondent Age & $\begin{array}{l}2.2 \% \text { (2) Between } 36 \text { and } 40 \text { years old } \\
11.1 \% \text { (10) Between } 41 \text { and } 45 \text { years old } \\
8.9 \% \text { (8) Between } 46 \text { and } 50 \text { years old } \\
23.3 \% \text { (21) Between } 51 \text { and } 55 \text { years old } \\
34.4 \% \text { (31) Between } 56 \text { and } 60 \text { years old } \\
20.0 \% \text { (18) Over } 60 \text { years old }\end{array}$ \\
\hline Disciplinary Area & $\begin{array}{c}26.7 \% \text { (24) Languages } \\
14.4 \% \text { (13) Mathematics and Informatics } \\
23.3 \% \text { (21) Experimental Sciences } \\
15.6 \% \text { (14) Human and Social Sciences } \\
\text { 20.6\% (18) Expressions }\end{array}$ \\
\hline
\end{tabular}

\subsection{Instruments and procedures}

The selection of the data collection instrument must take into account the aims to be achieved, as well as the population and the context in which the research takes place, so a questionnaire was developed based on other empirical studies [10, 20, 29, 30] and their items and dimensions have been adapted to the national context.

A questionnaire was chosen as the only data collection instrument, which must follow a set of procedures related to its preparation, organisation and availability, in order to guarantee its quality. In general, this instrument can be considered as "a set of items, questions or situations more or less organised and related to a certain domain to be assessed" [33].

For the set of variables that will help determine the acceptance and use of active ICT methodologies in the classroom as prescribed in the UTAUT model, the questionnaire was created and the Likert scale used from 1 to 5 to perform its measurement and collect and process information taking into account the constructs "performance expectancy", "effort expectancy", "ICT compatibility and self-efficacy", "motivation and involvement", "facilitating conditions", "system complexity" and "peer influence "(see table $3)$. 
Table 3. Constructs and scale items

\begin{tabular}{|c|c|c|c|}
\hline Construct & $\mathbf{N}^{\mathbf{0}}$ & Question & References \\
\hline $\begin{array}{c}P E \\
\text { Expectancy of } \\
\text { ICT performance } \\
\text { in pedagogical } \\
\text { activities }\end{array}$ & $\begin{array}{l}\text { PE1 } \\
\text { PE2 } \\
\text { PE3 } \\
\text { PE4 } \\
\text { PE5 }\end{array}$ & $\begin{array}{l}\text { The use of active methodologies with ICT: } \\
\text { - help to overcome learning difficulties. } \\
\text { - allow me to improve communication with all the actors in- } \\
\text { volved. } \\
\text { - match the current curricula. } \\
\text { - improve classroom teaching and learning. } \\
\text { - are easy to use and / or apply in the classroom. }\end{array}$ & $\begin{array}{l}{[5]} \\
{[24]} \\
{[30]}\end{array}$ \\
\hline $\begin{array}{c}\text { EE } \\
\text { Effort } \\
\text { Expectancy }\end{array}$ & $\begin{array}{l}\text { EE6 } \\
\text { EE7 } \\
\text { EE8 } \\
\text { EE9 }\end{array}$ & $\begin{array}{l}\text { The use of active methodologies with ICT: } \\
\text { - allow me to carry out my teaching activities more quickly. } \\
\text { - are easily accessible for the intended purpose. } \\
\text { - are easy to use for the intended purpose. } \\
\text { - make me feel that I have enough knowledge to skilfully } \\
\text { use ICT in the classroom. }\end{array}$ & $\begin{array}{l}{[5]} \\
{[30]} \\
{[13]}\end{array}$ \\
\hline $\begin{array}{c}\text { IC } \\
\text { ICT compatibility } \\
\text { and } \\
\text { self-efficacy }\end{array}$ & $\begin{array}{l}\text { IC10 } \\
\text { IC11 } \\
\text { IC12 }\end{array}$ & $\begin{array}{l}\text { Important and / or specific contents related to my classes are } \\
\text { available online. } \\
\text { The digital educational resources I use or intend to use are } \\
\text { adequate to my pedagogical objectives. } \\
\text { The digital educational resources are sufficiently updated for } \\
\text { my pedagogical objectives }\end{array}$ & [30] \\
\hline $\begin{array}{c}\text { ME } \\
\text { Motivation and } \\
\text { Personal In- } \\
\text { volvement }\end{array}$ & $\begin{array}{l}\text { MI13 } \\
\text { MI14 } \\
\text { MI15 } \\
\text { MI16 } \\
\text { MI17 }\end{array}$ & $\begin{array}{l}\text { I generally find it more attractive and interesting to use ICT } \\
\text { I like to try new ways to achieve my pedagogical activities. } \\
\text { I have a personal interest in information technology. } \\
\text { My experiences of using ICT in the classroom were posi- } \\
\text { tive. } \\
\text { I try to encourage my colleagues and students to use ICT in } \\
\text { their teaching and learning activities. }\end{array}$ & [30] \\
\hline $\begin{array}{c}\text { FC } \\
\text { Facilitating } \\
\text { Conditions }\end{array}$ & $\begin{array}{l}\text { FC18 } \\
\text { FC19 } \\
\text { FC20 } \\
\text { FC21 }\end{array}$ & $\begin{array}{l}\text { The network infrastructure and internet access are sufficient } \\
\text { for my teaching activities. } \\
\text { I have access to convenient computer equipment for my } \\
\text { teaching activities. } \\
\text { Adequate technical support is available when a technical } \\
\text { problem arises. } \\
\text { There is pedagogical support available to help me use ICT. }\end{array}$ & $\begin{array}{l}{[5]} \\
{[30]} \\
{[10]}\end{array}$ \\
\hline $\begin{array}{c}\text { SC } \\
\text { System } \\
\text { Complexity }\end{array}$ & $\begin{array}{l}\mathrm{SC} 22 \\
\mathrm{SC} 23\end{array}$ & $\begin{array}{l}\text { It took me a long time to learn how to use ICT in my teach- } \\
\text { ing activities. } \\
\text { It is very difficult to learn how to use ICT (internet, com- } \\
\text { puter, platforms, smartphones, apps) to carry out teaching } \\
\text { and learning activities. } \\
\text { I am "sometimes" insecure when I use ICT activities in the } \\
\text { classroom. }\end{array}$ & $\begin{array}{l}{[5]} \\
{[30]}\end{array}$ \\
\hline $\begin{array}{c}\text { PI } \\
\text { Peer } \\
\text { Influence }\end{array}$ & $\begin{array}{l}\text { PI25 } \\
\text { PI26 } \\
\text { PI27 } \\
\text { PI28 }\end{array}$ & $\begin{array}{l}\text { The use of active methodologies with ICT in the classroom: } \\
- \text { is in line with my school's vision; } \\
\text { - has the support of the Board; } \\
\text { - is aligned with my department colleagues' desire for } \\
\text { change; } \\
- \text { is being promoted by other schoolmates. }\end{array}$ & [30] \\
\hline
\end{tabular}

Now the exploratory statistical results are presented, performing a factor analysis through the factor analysis of main components on the different constructs to explore the structure and test its reliability. In this phase of purification of measurement scales, the results will be explained and justified. 
Next, the results of the confirmatory analysis will be presented. The regression tests were performed on the different scales collected through factor analysis. The results will be presented and justified.

The calculations were performed using statistical analysis software, the SPSS statistic version 26.

\subsection{Data analysis and validation}

For the normality of the results analysis, Kurtosis and Skewness represent the two indexes normally used for this purpose. To highlight the results obtained, the histograms can be analysed thus allowing to visualise the distribution of responses (see annex II). A good distribution in most of the items was found and there was no significant gap from a normal curve, since part of the items have a homogeneous distribution and others have a sometimes accentuated asymmetric one. However, all the results obtained were accepted.

Regarding the sample $(n=90)$ used in the exploratory phase, it complies with the necessary condition to carry out a commonality analysis of the items since it has 5 to 10 times more individuals than items introduced in the same analysis [33].

Then there was a purification of the measurement scales, carrying out, in a first exploratory phase, an analysis of the commonality of the items and an estimate of viability using Cronbach's Alpha on each measurement scale. This coefficient is an inherent property of the response pattern of the studied population, that is, the alpha value may change according to the population which the instrument is applied to [34]. The alpha value varies between 0 and 1 and can have the following readings: (i) greater than 0.9 - very good consistency, (ii) between 0.8 and 0.9 - good, (iii) between 0.7 and 0.8 reasonable, (iv) between 0.6 and 0.7 - weak, (v) less than 0.6 - inadmissible. According to Streiner [34] values between 0.8 and 0.9 should be chosen, given that the minimum acceptable value for alpha is 0.7 and values above 0.9 may indicate redundancy of the items.

In this first phase, the validity of the constructs of the initial scale was carried out, trying to question whether the different indicators offer us a good representation of the phenomenon under study. It is necessary to check if the indicators that aim to measure the same phenomenon are sufficiently correlated (convergent validity) and are distinguished from the indicators that seek to measure different phenomena (discriminant validity) [34]. It is convenient to remove items whose commonality is less than 0.5 , since they do not share a sufficient variance with others that, alone, form a factor. The Cronbach's Alpha test (reliability coefficient) allows us to measure the internal coherence of the construct from the set of items that compose it.

In this purification phase, the scales are generally satisfactory and have a good level of reliability. Only item EE9 was eliminated from the effort expectancy construct due to its poor commonality (0.195). Table 4 shows the results of the exploratory analysis.

Confirmatory analysis will now aim to operationalise the concepts and test the significance of the constructs. 
Table 4. Exploratory analysis

\begin{tabular}{|c|c|c|c|c|c|}
\hline $\begin{array}{l}\text { Con- } \\
\text { struct }\end{array}$ & Item & Measure used & $\begin{array}{l}\text { Convergent } \\
\text { validity }\end{array}$ & $\begin{array}{r}\text { Variance } \\
\text { explained }\end{array}$ & $\begin{array}{l}\text { Cronbach's } \\
\text { alpha } \\
\text { reliability } \\
\end{array}$ \\
\hline \multirow{5}{*}{ PE } & PE1 & $\begin{array}{l}\text { The use of active methodologies with ICT help to } \\
\text { overcome learning difficulties. }\end{array}$ & 0,820 & \multirow{5}{*}{$68,610 \%$} & \multirow{5}{*}{0,883} \\
\hline & PE 2 & $\begin{array}{l}\text { The use of active ICT methodologies allows me to } \\
\text { improve communication by all the actors involved. }\end{array}$ & 0,866 & & \\
\hline & PE 3 & $\begin{array}{l}\text { The use of active ICT methodologies is in line with } \\
\text { the current curricula. }\end{array}$ & 0,813 & & \\
\hline & PE 4 & $\begin{array}{l}\text { The use of active ICT methodologies improves } \\
\text { teaching and learning in the classroom. }\end{array}$ & 0,865 & & \\
\hline & PE 5 & $\begin{array}{l}\text { The use of active ICT methodologies are easy to } \\
\text { use and / or apply in the classroom. }\end{array}$ & 0,774 & & \\
\hline \multirow{3}{*}{$\mathbf{E E}$} & EE6 & $\begin{array}{l}\text { The use of active methodologies with ICT allow me } \\
\text { to carry out my teaching activities more quickly. }\end{array}$ & 0,810 & \multirow{3}{*}{$79 \%$} & \multirow{3}{*}{0,784} \\
\hline & EE7 & $\begin{array}{l}\text { The use of active ICT methodologies is easily ac- } \\
\text { cessible for the intended purpose. }\end{array}$ & 0,933 & & \\
\hline & EE8 & $\begin{array}{l}\text { The use of active ICT methodologies is easy to use } \\
\text { for the intended purpose. }\end{array}$ & 0,920 & & \\
\hline \multirow{3}{*}{ IC } & CT10 & $\begin{array}{l}\text { Important and / or specific contents related to my } \\
\text { classes are available online. }\end{array}$ & 0,660 & \multirow{3}{*}{$77 \%$} & \multirow{3}{*}{0,850} \\
\hline & CT11 & $\begin{array}{l}\text { The digital educational resources that I use or in- } \\
\text { tend to use are adequate to my pedagogical objec- } \\
\text { tives. }\end{array}$ & 0,817 & & \\
\hline & CT12 & $\begin{array}{l}\text { The digital educational resources are sufficiently } \\
\text { updated for my pedagogical goals. }\end{array}$ & 0,839 & & \\
\hline \multirow{5}{*}{ MI } & MI13 & $\begin{array}{l}\text { I generally find it more attractive and interesting to } \\
\text { use ICT. }\end{array}$ & 0,810 & \multirow{5}{*}{$70 \%$} & \multirow{5}{*}{0,889} \\
\hline & MI14 & $\begin{array}{l}\text { I like to try new ways to achieve my pedagogical } \\
\text { activities. }\end{array}$ & 0,824 & & \\
\hline & MI15 & $\begin{array}{l}\text { I have a personal interest in information technol- } \\
\text { ogy. }\end{array}$ & 0,807 & & \\
\hline & MI16 & $\begin{array}{l}\text { My experiences of using ICT in the classroom were } \\
\text { positive. }\end{array}$ & 0,860 & & \\
\hline & MI17 & $\begin{array}{l}\text { I try to encourage my colleagues and students to try } \\
\text { the use of ICT in their teaching and learning activi- } \\
\text { ties. }\end{array}$ & 0,869 & & \\
\hline \multirow{4}{*}{ FC } & FC18 & $\begin{array}{l}\text { The network infrastructure and internet access are } \\
\text { sufficient for my teaching activities. }\end{array}$ & 0,661 & \multirow{4}{*}{$65 \%$} & \multirow{4}{*}{0,817} \\
\hline & FC19 & $\begin{array}{l}\text { I have access to convenient computer equipment for } \\
\text { my teaching activities. }\end{array}$ & 0,741 & & \\
\hline & FC20 & $\begin{array}{l}\text { Adequate technical support is available when a } \\
\text { technical problem arises. }\end{array}$ & 0,476 & & \\
\hline & FC21 & $\begin{array}{l}\text { There is pedagogical support available to help me } \\
\text { use ICT. }\end{array}$ & 0,726 & & \\
\hline $\mathrm{SC}$ & SC22 & $\begin{array}{l}\text { It took me a long time to learn how to use ICT for } \\
\text { my teaching activities. }\end{array}$ & 0.838 & $72 \%$ & 0,798 \\
\hline
\end{tabular}




\begin{tabular}{|c|c|c|c|c|c|}
\hline $\begin{array}{l}\text { Con- } \\
\text { struct }\end{array}$ & Item & Measure used & $\begin{array}{l}\text { Convergent } \\
\text { validity }\end{array}$ & $\begin{array}{r}\text { Variance } \\
\text { explained }\end{array}$ & $\begin{array}{l}\text { Cronbach's } \\
\text { alpha } \\
\text { reliability } \\
\end{array}$ \\
\hline & $\mathrm{SC} 23$ & $\begin{array}{l}\text { It is very difficult to learn how to use ICT (internet, } \\
\text { computer, platforms, smartphones, apps) to carry } \\
\text { out teaching and learning activities. }\end{array}$ & 0.853 & & \\
\hline & $\mathrm{SC} 24$ & $\begin{array}{l}\text { I sometimes "feel" insecure when I use ICT activi- } \\
\text { ties in the classroom. }\end{array}$ & 0,855 & & \\
\hline \multirow{4}{*}{ PI } & PI25 & $\begin{array}{l}\text { The use of active ICT methodologies is in line with } \\
\text { my school's vision }\end{array}$ & 0,795 & \multirow{4}{*}{$61 \%$} & \multirow{4}{*}{0,782} \\
\hline & PI26 & $\begin{array}{l}\text { The use of active ICT methodologies is supported } \\
\text { by the Board. }\end{array}$ & 0,849 & & \\
\hline & PI27 & $\begin{array}{l}\text { The use of active ICT methodologies is aligned } \\
\text { with my department colleagues' desire for change; }\end{array}$ & 0,705 & & \\
\hline & PI28 & $\begin{array}{l}\text { The use of active ICT methodologies is being pro- } \\
\text { moted by other school colleagues. }\end{array}$ & 0,775 & & \\
\hline
\end{tabular}

The linear correlation coefficient makes it possible to measure the strength and direction of the linear connection between two scalar variables. The bivariate correlations between two or more variables are summarised in table 5 .

Table 5. Correlations between the different dimensions

\begin{tabular}{|c|c|c|c|c|c|c|c|c|}
\hline & & PE & EE & IC & MI & FC & $\mathrm{SC}$ & PI \\
\hline \multirow{3}{*}{$\mathbf{P E}$} & Pearson's correlation & 1 & & & & & & \\
\hline & Sig. (2 ends) & & & & & & & \\
\hline & $\mathrm{N}$ & 90 & & & & & & \\
\hline \multirow{3}{*}{$\mathbf{E E}$} & Pearson's correlation &, $744^{* *}$ & 1 & & & & & \\
\hline & Sig. (2 ends) & ,000 & & & & & & \\
\hline & $\mathrm{N}$ & 90 & 90 & & & & & \\
\hline \multirow{3}{*}{ IC } & Pearson's correlation & $698^{* *}$ &, $616^{* *}$ & 1 & & & & \\
\hline & Sig. (2 ends) & ,000 & ,000 & & & & & \\
\hline & $\mathrm{N}$ & 90 & 90 & 90 & & & & \\
\hline \multirow{3}{*}{ MI } & Pearson's correlation & ,661 &, $512^{* *}$ &, $726^{* *}$ & 1 & & & \\
\hline & Sig. (2 ends) & ,000 & ,000 & ,000 & & & & \\
\hline & $\mathrm{N}$ & 90 & 90 & 90 & 90 & & & \\
\hline \multirow{3}{*}{$\mathbf{F C}$} & Pearson's correlation &, $568^{* * *}$ &, $500^{* *}$ & ,654 & ,605 & 1 & & \\
\hline & Sig. (2 ends) & ,000 & ,000 & ,000 & ,000 & & & \\
\hline & $\mathrm{N}$ & 90 & 90 & 90 & 90 & 90 & & \\
\hline \multirow{3}{*}{$\mathrm{SC}$} & Pearson's correlation &,- 077 &,- 104 &,$- 225^{*}$ &,$- 401^{* *}$ &,$- 223^{*}$ & 1 & \\
\hline & Sig. (2 ends) & 472 & 330 & ,033 & ,000 & ,035 & & \\
\hline & $\mathrm{N}$ & 90 & 90 & 90 & 90 & 90 & 90 & \\
\hline \multirow{3}{*}{ PI } & Pearson's correlation & ,667 &, $705^{* *}$ &, $597^{* * *}$ &, $483^{* *}$ &, $630^{* *}$ & ,106 & 1 \\
\hline & Sig. (2 ends) & ,000 & ,000 & ,000 & ,000 & ,000 & ,319 & \\
\hline & $\mathrm{N}$ & 90 & 90 & 90 & 90 & 90 & 90 & 90 \\
\hline
\end{tabular}

**. The correlation is significant at the 0.01 level ( 2 ends).

*. The correlation is significant at the 0.05 level (2 ends). 
The Pearson correlation coefficient used is a measure of association that permits to verify whether two variables measured, in the same observation set, vary analogously or not - a correlation close to 1 or -1 in absolute value means that the two variables are linearly linked and can be mutually explained. However, correlation is not synonymous with causality. So that a variable $\mathrm{X}$ causes a variable $\mathrm{Y}$, it is necessary that:

- $\mathrm{X}$ and $\mathrm{Y}$ are correlated;

- In a sequential way, it is necessary that $X$ intervenes in the time before $Y$, that is, the argument about the sequence of variables is often theoretical or based on intuition;

$-\mathrm{X}$ and $\mathrm{Y}$ are not caused by the same variable, which in this case would explain their connection.

- When analysing Table 5, we found a stronger relationship between:

- The performance expectancy and the effort expectancy that are positively linked ( $\mathrm{r}$ $=744$, Sig. $<0.01$ )

- The effort expectancy and the peers influence that are positively connected $(r=705$, Sig. <0.01)

- ICT compatibility and motivation and involvement that are positively linked $(\mathrm{r}=$ 726, Sig. <0.01)

It was also observed that the variable complexity of the system is not significantly linked to the variables performance expectancy, effort expectancy system complexity, facilitating conditions and peer influence and more significantly linked to motivation and involvement. These more significant correlations are negative, which means that the variables involved vary in the opposite direction. In this case, for example, if the complexity of the system increases, motivation and involvement decrease, that is, the more the complexity of the system increases, the less respondents think that motivation and involvement will be achieved.

This (negative) effect is due to the fact that, when creating the questionnaire, for a better understanding of it, we inverted the meaning of the questions. The remaining correlations between the variables are significant as a whole.

\section{$5 \quad$ Results}

Then the tests to validate the proposed hypotheses were carried out. To test the effects of the independent variables on the dependent variable, the linear regression method was used in order to find the presence of an effect and deduce the intensity of the effect. This method is widely used to predict a variable (the dependent variable) from another or other variables. It is important to refer that what is highlighted is a statistical relationship, which is not synonymous with cause and effect, and that only our analysis and knowledge of the context can allow explanations that remain hypothetical.

A simple regression with an independent and a dependent variable was applied, the latter being used for all relationships (see table 6); 
Table 6. Correlations between the different dimensions

\begin{tabular}{|l|c|c|c|c|}
\hline \multirow{2}{*}{\multicolumn{1}{c|}{$\begin{array}{c}\text { Dependent variable } \\
\text { Independent variable }\end{array}$}} & \multicolumn{4}{c|}{ Motivation and Involvement } \\
\cline { 2 - 5 } & $\boldsymbol{\beta}$ & $\boldsymbol{R} 2$ & $\boldsymbol{C o e f} . \boldsymbol{F}$ & Sign. $\boldsymbol{F}$ \\
\hline Performance Expectancy & 0,661 & 0,437 & 68,229 & 0.000 \\
\hline Effort Expectancy & 0,512 & 0,262 & 31,198 & 0.000 \\
\hline ICT compatibility & 0,726 & 0,522 & 98,134 & 0.000 \\
\hline Facilitating Conditions & 0,605 & 0,366 & 50,819 & 0.000 \\
\hline System Complexity & $-0,401$ & 0,161 & 16,825 & 0.000 \\
\hline Peer Influence & 0,483 & 0,234 & 26,834 & 0.000 \\
\hline
\end{tabular}

The PE explains $43.7 \%\left(\mathrm{R}^{2}=0.437\right)$ of the MI, and that it has a significant positive influence on MI $(\beta=0.661 ; p<0.001)$. Comparing with the UTAUT model, the PE variable is one of the most predictive variables in our model. These results suggest that the stronger the PE of the use of ICT in the classroom, the higher the teachers' MI and, consequently, their intention and / or use of them in the classroom. These results vindicate the ones included in the works of Venkatesh, Morris, Davis, \& Davis [5] and Venkatesh, Thong, \& Xu [35].

The EE explains only $26.2 \%\left(\mathrm{R}^{2}=0.262\right)$ of $\mathrm{MI}$ (which is a low value), and a significant positive influence on motivation and involvement $(\beta=0.512 ; p<0.001)$. Compared with the UTAUT model, the EE variable is one of the significant predictive variables in our model. These results suggest that the stronger the EE of the use of ICT in the classroom, the greater will be the motivation and involvement of the teachers and, therefore, their intention to use and / or their effective use in the classroom. These results support the results exposed in the works of Venkatesh, Morris, Davis, \& Davis [5] and Venkatesh, Thong, \& Xu [35]

In its turn, the IC explains $52.2 \%\left(\mathrm{R}^{2}=0.522\right)$ of MI, and has a significant positive influence on MI $(\beta=0.726 ; p<0.001)$. Compared with the UTAUT model, the IC is one of the very significant predictive variables in our model. These results indicate that the stronger the IC for the use of ICT in the classroom, the greater the motivation and involvement of the teachers and, so, their intention and / or use of them in the classroom. These results corroborate the results registered in the works of Venkatesh, Morris, Davis, \& Davis [5] and Venkatesh, Thong, \& Xu, [35].

The FC explain $36.6 \%\left(\mathrm{R}^{2}=0.366\right)$ of MI, and that they have a significant positive influence on motivation and involvement $(\beta=0.605 ; \mathrm{p}<0.001)$. In comparison with the UTAUT model, the FC is one of the predictive variables in our model. These results show that the stronger the FC for the use of ICT in the classroom, the greater the motivation and involvement of the teachers and, therefore, their intention to use and / or their effective use in the classroom. These results confirm the ones included in the works of Venkatesh, Morris, Davis, \& Davis [5] and Venkatesh, Thong, \& Xu [35].

As for the SC, it explains $16.1 \%\left(\mathrm{R}^{2}=0.161\right)$ of $\mathrm{MI}$, and has a significant negative influence on MI $(\beta=-0.401 ; p<0.001)$. These results imply that the stronger the SC for the use of ICT in the classroom, the lower the motivation and involvement of the students and, consequently, their intention to use and / or their effective use in the classroom. 
The PI explains $23.4 \%\left(\mathrm{R}^{2}=0.234\right)$ of $\mathrm{MI}$, and has a significant positive influence on MI $(\beta=0.483 ; p<0.001)$, which indicates that the stronger the PI for the use of ICT in the classroom, the greater the motivation and involvement of the teachers and, this way, their intention to use and / or the effective use of them in the classroom. These results validate the ones described in the works of Venkatesh, Morris, Davis, \& Davis [5] and Venkatesh et al. [9].

Considering the results, all hypotheses were accepted.

\section{Discussion of results}

In the different UTAUT studies mentioned in our literature review, they were mostly focused on the adoption of a certain technology, which is properly identified and studied. In our study, we sought to investigate further and, in this sense, our focus was on the pedagogical use in the classroom of various technologies without specifying one or the other, in particular. The validation of our hypotheses allows us to identify the factors that explain the motivation and involvement of the teachers and, therefore, their intention to use or effectively use ICT in the classroom.

The results show that PE has a significant influence on teachers' MI in the use of ICT. PE is one of the fundamental variables of the UTAUT model [9] confirmed by other studies $[34,10]$. In our case, teachers believe that the use of ICT in the classroom can help to overcome communication and learning difficulties, that ICT are aligned with the current curricula and that they need to be easily used and / or applied in the classroom.

The significant influence presented by the results of EE on MI, allows us to conclude that teachers believe that the use of ICT helps them to perform tasks more quickly and that they are easy to access and use. EE is also very related to PE, that is, if the PE increases, it also increases the EE and the higher the MI of the teachers will be. As for IC, they have a significant influence on MI; for our study it was important to verify the positive effect that digital educational resources represent for the teachers, who are able to find in them a panoply of contents and activities that meet the programs they teach.

FC have a significant influence on MI, which in our context shows that the investment made in technology, training, pedagogical and technological support have an influence on MI, and it is still necessary to find a way to improve adequate technical support when a problem arises in the classroom.

SC has a significant negative influence on MI: the more difficult and time-consuming it is to learn to use ICT and the more insecure the teacher is, the smaller the MI will be. In our case, we can observe that our teachers, in general, do not feel insecure and learn to use ICT with some ease.

The results also show a significant influence of the PI on MI: teachers feel involved with the school's vision, with the desire for change, with the support of the Board and with the use of ICT by department colleagues. 


\section{Conclusions}

The proliferation of ICT in the classroom has been "timidly" increasing over the years and different models of technology adoption have been developed to explain the factors that can influence their use. This study aimed to study the degree of acceptance of active methodologies with ICT, in the classroom, using, for this purpose, the UTAUT model. From a theoretical point of view, it validated the presence of the model variables after being adapted to the context our study.

This study permitted a reflection on how teachers are adopting technology, how they reformulate their practices, and what are the factors that cause their motivation and involvement to increase and, thus, also their effective use. PE and IC are the most influential variables in the model: they cause, on the one hand, to believe that the use of a particular ICT resource will increase their pedagogical performance and, thus, the student's learning results, and, on the other hand, the teacher's belief in easily finding tools and contents in ICT that meet their syllabus and pedagogical needs. It is, therefore, essential to reinforce the appropriate skills for using ICT in the classroom and to provide digital educational applications, tools and resources that meet the expectations and needs of teachers.

The identified need for support challenges the school's management to create the figure of a Learning Designer, Educational Designer or Learning Technologist focused on the excellence of education, seeking to understand the relationship between technology and learning. The exercise of this role should mobilize the school to create networks that promote change, innovation and inclusion, under the commitment to disseminate good practices in the use of technology in education.

Access to technology, the technological conditions of the school, support from peers and management are, among others, determining factors for its adoption and use in the classroom.

From the study carried out, it is possible to perceive, as underlying the good use of technology in education, the relevance of how innovation and change are managed. This is, in itself, a critical success factor in the organizational plan, which must be led by a motivated team, supported by those who lead the institution and close to the teachers, with technological competence and broad pedagogical vision. Thus, the dimensions identified in table 6 are critical success factors to consider when managing innovation in technology-rich environments in teaching and learning.

The context of accomplishment was identified as a significant limitation of the study since it was developed in a school with a structured network, wi-fi access and, at least, a computer, a video projector and Internet access in each classroom, and with teachers who have access to training and support for the pedagogical adequacy of the use of technology in the classroom.

\section{Conflict of Interest}

The author declares no conflict of interest. 


\section{References}

[1] B. Pynoo, P. Devolder, J. Tondeur, J. Van Braak, W. Duyck, and P. Duyck, "Predicting secondary school teachers' acceptance and use of a digital learning environment: A crosssectional study," Comput. Human Behav., 2011. https://doi.org/10.1016/j.chb.2010.10.005

[2] P. Holzmann, E. J. Schwarz, and D. B. Audretsch, "Understanding the determinants of novel technology adoption among teachers: the case of 3D printing," J. Technol. Transf., vol. 45, no. 1, pp. 259-275, 2018. https://doi.org/10.1007/s10961-018-9693-1

[3] S. A. Ferreira, C. Castro, and A. Andrade, "Morfologia da Comunicação Cognitiva 2.0 em sala de aula no âmbito do Ensino Superior," Cisti, pp. 294-300, 2011.

[4] B. Šumak and A. Šorgo, "The acceptance and use of interactive whiteboards among teachers: Differences in UTAUT determinants between pre- and post-adopters," Comput. Human Behav., 2016. https://doi.org/10.1016/j.chb.2016.07.037

[5] V. Venkatesh, M. G. Morris, G. B. Davis, and F. D. Davis, "User acceptance of information technology: Toward a unified view," MIS Q. Manag. Inf. Syst., vol. 27, no. 3, pp. 425-478, 2003. https://doi.org/10.2307/30036540

[6] M. Fishbein and I. Ajzen, "Belief, attitude, intention and behavior: An introduction to theory and research," Maddison-Wesley Publ. Co., 1975.

[7] F. D. Davis, R. P. Bagozzi, and P. R. Warshaw, "User Acceptance of Computer Technology: A comparision of two theoretical models." 1989.

[8] I. Ajzen, "From Intentions to Actions: A Theory of Planned Behavior," in Action Control, Springer Berlin Heidelberg, 1985, pp. 11-39. https://doi.org/10.1007/978-3-642-69746-3 2

[9] V. Venkatesh, M. G. Morris, G. B. Davis, and F. D. Davis, "User acceptance of information technology," Int. Encycl. Ergon. Hum. Factors, Second Ed. - 3 Vol. Set, vol. 27, no. 3, pp. 425-478, 2003. https://doi.org/10.2307/30036540

[10] M. Ma, J. Chen, P. Zheng, and Y. Wu, "Interactive Learning Environments Factors affecting EFL teachers' affordance transfer of ICT resources in China," 2019. https://doi.org/10. $1080 / 10494820.2019 .1709210$

[11] F. D. Davis, "Perceived usefulness, perceived ease of use, and user acceptance of information technology," MIS Q. Manag. Inf. Syst., vol. 13, no. 3, pp. 319-339, 1989. https://doi.org/10.2307/249008

[12] A. Dillon and M. G. Morris, "User Acceptance of Information Technology: Theories and Models," Annu. Rev. Inf. Sci. Technol., vol. 31, no. July, pp. 3-32, 1996.

[13] M. Gellerstedt, S. M. Babaheidari, and L. Svensson, "A first step towards a model for teachers' adoption of ICT pedagogy in schools," Heliyon, vol. 4, no. 9, p. e00786, 2018. https://doi.org/10.1016/j.heliyon.2018.e00786

[14] N. Jan van Eck and L. Waltman, "Software survey: VOSviewer, a computer program for bibliometric mapping.". https://doi.org/10.1007/s11192-009-0146-3

[15] L. Bradin, “Análise de conteúdo,” Edição Rev. e Actual. ed. Lisboa, vol. Edições 70, 2008.

[16] H. Yildiz Durak, Examining the acceptance and use of online social networks by preservice teachers within the context of unified theory of acceptance and use of technology model, vol. 31, no. 1. Springer US, 2019. https://doi.org/10.1007/s12528-018-9200-6

[17] V. Terzis and A. A. Economides, "The acceptance and use of computer based assessment," Comput. Educ., 2011.

[18] P. J. B. Tan, "Applying the UTAUT to understand factors affecting the use of english elearning websites in Taiwan," SAGE Open, vol. 3, no. 4, 2013. https://doi.org/10.1177/ 2158244013503837

[19] B. Tosuntaş, E. Karadał, and S. Orhan, "The factors affecting acceptance and use of interactive whiteboard within the scope of FATIH project: A structural equation model 
based on the Unified Theory of acceptance and use of technology," Comput. Educ., 2015. https://doi.org/10.1016/j.compedu.2014.10.009

[20] S. Lin, J. C. Zimmer, and V. Lee, "Podcasting acceptance on campus: The differing perspectives of teachers and students," Comput. Educ., 2013.

[21] M. El-Masri, - Ali Tarhini, and A. Tarhini, "Factors affecting the adoption of e-learning systems in Qatar and USA: Extending the Unified Theory of Acceptance and Use of Technology 2 (UTAUT2)," vol. 65, pp. 743-763, 2017. https://doi.org/10.1007/s11423016-9508-8

[22] A. Birch and V. Irvine, "Preservice teachers' acceptance of ICT integration in the classroom: Applying the UTAUT model," EMI. Educ. Media Int., vol. 46, no. 4, pp. 295-315, 2009. https://doi.org/10.1080/09523980903387506

[23] B. Šumak, G. Polančič, and M. Heričko, "An empirical study of virtual learning environment adoption using UTAUT," 2nd Int. Conf. Mobile, Hybrid, On-Line Learn. eL mL 2010, pp. 17-22, 2010. https://doi.org/10.1109/elml.2010.11

[24] N. G. Uğur and A. H. Turan, "E-learning adoption of academicians: a proposal for an extended model," Behav. Inf. Technol., vol. 37, no. 4, pp. 393-405, 2018. https://doi.org/10.1080/0144929x.2018.1437219

[25] I. Bourdon and S. Hollet-Haudebert, "Pourquoi contribuer à des bases de connaissances ? Une exploration des facteurs explicatifs à la lumière du modèle UTAUT," Systèmes d'information Manag., vol. 14, no. 1, p. 9, 2009. https://doi.org/10.3917/sim.091.0009

[26] S. Villeneuve, T. Karsenti, and S. Collin, "Factors influencing the use of information and communication technologies among practice teachers at the secondary level," Éducation Francoph., vol. 41, no. 1, pp. 30-44, 2013.

[27] Á. M. Aliaño, A. M. D. Hueros, M. D. G. Franco, and I. Aguaded, "Mobile learning in university contexts based on the unified theory of acceptance and use of technology (UTAUT)," J. New Approaches Educ. Res., vol. 8, no. 1, pp. 7-17, Jan. 2019. https://doi.org /10.7821/naer.2019.1.317

[28] C. M. Chao, "Factors determining the behavioral intention to use mobile learning: An application and extension of the UTAUT model," Front. Psychol., vol. 10, no. JULY, 2019. https://doi.org/10.3389/fpsyg.2019.01652

[29] U. N. O. F. I. Badan and N. Igeria, "Performance Expectancy, Effort Expectancy, and Facilitating Conditions as Factors Influencing Smart Phones Use for Mobile Learning by Postgraduate Students of the University of Ibadan, Nigeria," Interdiscip. J. e-Skills Lifelong Learn., vol. 14, pp. 095-115, 2018. https://doi.org/10.28945/4085

[30] K. S. Kouakou, "Determinants of adoption of social digital networks by Ivory Coast university librarians," Frantice.net, vol. 9, pp. 54-73, 2014.

[31] E. Karahanna, D. W. Straub, and N. L. Chervany, "Information technology adoption across time: A cross-sectional comparison of pre-adoption and post-adoption beliefs," MIS $Q$. Manag. Inf. Syst., vol. 23, no. 2, pp. 183-213, 1999. https://doi.org/10.2307/249751

[32] G. C. Moore and I. Benbasat, "Development of an Instrument to Measure the Perceptions of Adopting an IT Innovation," Information Systems Research, vol. 2, no. 3. pp. 192-222, 1991. https://doi.org/10.1287/isre.2.3.192

[33] L. S. Almeida and T. Freire, Metodologias da investigação em psicologia e educação, $5^{\circ}$. 2017.

[34] D. L. Streiner, "Statistical Developments And Applications Being Inconsistent About Consistency: When Coefficient Alpha Does and Doesn't Matter Streiner Scales And Indexes,” 2003. https://doi.org/10.1207/s15327752jpa8003_01 
[35] V. Venkatesh, J. Y. L. Thong, and X. Xu, "Unified theory of acceptance and use of technology: A synthesis and the road ahead," J. Assoc. Inf. Syst., vol. 17, no. 5, pp. 328-376, 2016.

\section{Authors}

Francisco José Miranda Veiga, PhD student at CEDH - Centro de Estudos para o Desenvolvimento Humano Universidade Católica Portuguesa, in Educational Sciences, with a degree in management informatics and a master's degree in information systems. Teacher and Assistant Director of a School.

António Manuel Valente de Andrade, Associate Professor in Information Systems and Education at CEDH - Centro de Estudos para o Desenvolvimento Humano Universidade Católica Portuguesa. PhD in Technology and Information Systems from the University of Minho - Portugal. Master in Management and Information Systems and degree in Mathematics.

Article submitted 2021-04-07. Resubmitted 2021-06-28. Final acceptance 2021-06-29. Final version published as submitted by the authors. 